JPPUMA: Jurnal Ilmu Pemerintahan dan Sosial Politik UMA (Journal of Governance and Political Social UMA),

8 (1) (2020): 47-56, DOI: https://doi.org/10.31289/ippuma.v8i1.3207

JPPUMA: Jurnal Ilmu Pemerintahan dan Sosial Politik UMA

(Journal of Governance and Political Social UMA)

Available online http://ojs.uma.ac.id/index.php/jppuma

\title{
Social Image and Candidate's Image: A Case Study of Voting Behavior in the Gubernatorial Election in Indonesia's West Java in 2018
}

\author{
Hermansyah Putra*, R. Widyasetiabudi Sumadinata \& Affan Sulaeman \\ Political Science Study Program, Postgraduate Faculty of Social and Political Sciences \\ Universitas Padjadjaran, Indonesia
}

Recieved: December 15, 2019; Accepted: February 21, 2020; Published: June 01, 2020

\begin{abstract}
This article aims to discuss the behavior of voters in the City of Sukabumi in the Gubernatorial Election of West Java Province in 2018. This research is motivated by the anomaly of the survey results. A pair of candidates who were unseeded before obtained an increase of votes unpredictably. This research focuses on the pattern of behavior of citizens in determining their choices regarding the election. This research applies the cognitive domain model theory to study the pattern of voting behavior. In collecting data, the author distributed questionnaires to 140 respondents chosen from the official voters' list. The distribution of sample areas uses stratified random sampling techniques. The author analyzes data by using multinomial logistic regression. This study concludes that social image and candidates' images partially become the main consideration in voting behavior. Social image is the only significant factor that influences the voters in deciding their choice. This study concludes that the psychological approach becomes the main basis that underlies the voting behavior of voters and the main identification of the candidate.

Keywords: voting behavior, social image, candidate image, Gubernatorial Election, West Java
\end{abstract}

How to Cite: Putra, H, Sumadinata, R.W \& Sulaeman, A (2020). Social Image and Candidate's Image: A Case Study of Voting Behavior in the Gubernatorial Election in Indonesia's West Java in 2018. JPPUMA: Jurnal Ilmu Pemerintahan dan Sosial Politik UMA (Journal of Governance and Political Social UMA), 8(1): 47-56

${ }^{*}$ Corresponding author:

ISSN 2549-1660 (Print)

E-mail: herman@gmail.com

ISSN 2550-1305 (Online) 


\section{INTRODUCTION}

As many as 171 regions in Indonesia implemented the third Regional Election simultaneously on June 27 in 2018. It is including in the West Java Province. In West Java, there are four pairs of candidates of governor and deputy governor. Consecutively based on the candidates' number, they are 1) $\mathrm{M}$. Ridwan Kamil and UU Ruzhanul Ulum (RINDU); 2) Tubagus Hasanudin and Anton Charliyan (HASANAH); 3) Sudrajat and Ahmad Syaiku (ASYIK); 4). Dedi Mizwar and Dedi Mulyadi (Duo DM). Regarding this Gubernatorial Election, several credible polling institutes conducted several pre-election electability surveys. The surveys took place in the course of the campaign period. The survey reveals that RINDU always obtains the top position. This candidate is followed consecutively by DUO DM in the second place and ASYIK in third place, and HASANAH at the last position.
It is interesting that in this contestation, five of eight candidates who nominated themselves are the incumbent District Heads, such as Ridwan Kamil (Mayor of Bandung), UU Ruzhanul Ulum (Mayor of Tasik), Dedi Mulyadi (District Head of Purwakarta), Dedi Mizwar (Deputy Governor), Ahmad Syaiku (Deputy Mayor of Bekasi). Their track record as the incumbent gives an impression to the public that during their reign, which is the candidates have been known, at least by people from their district's area. This popularity will benefit the candidates and more or less will affect their electability before the election. The polling survey shows that the electability of the candidates is in line with their popularity. Three candidates who are not incumbent (Sudrajat, Tubagus Hasanudin, and Anton Charliyan) always obtained the lowest position in electability with the only one-digit number.

Tabele 1 Recapitulation of votes in the Gubernatorial Election in West Java in 2018

\begin{tabular}{lllll}
\hline No & Candidates' names & Votes & Percentage & Rank \\
\hline 1 & M. Ridwan Kamil dan UU Ruzhanul Ulum & 7.226 .254 & 32,88 & 1 \\
\hline 2 & Tubagus Hasanudin dan Anton Charliyan & 2.773 .078 & 12,68 & 4 \\
\hline 3 & Sudrajat dan Ahmad Syaiku & 6.317 .465 & 28,74 & 2 \\
\hline 4 & Dedi Mizwar dan Dedi Mulyadi & 5.663198 & 25,77 & 3 \\
\hline & Total & 21.979 .995 & 100 & \\
\hline
\end{tabular}

Source: Model DC-KWK KPU Provinsi Jabar 2018 (KPU, 2018)

A remarkable thing of the Election's result is that there is a significant increase of votes for ASYIK candidates. The result of the election disproves the results of the previous polling survey, in which a lower electability candidates RINDU outstrip the candidates DUO DM and won the 2018 Election by a difference of only about $4 \%$ of the votes. This anomaly between the survey and the results of the votes became a particular phenomenon of the West Java Gubernatorial Election in 2018. Another particular phenomenon is a paradox between the electability and the victory of the RINDU Candidate and the votes in Sukabumi City.

Table 2 Recapitulation of votes in the 2018 Gubernatorial Election of West Java di Sukabumi City

\begin{tabular}{lllll}
\hline No & Candidates' names & Votes & Percentage & Rank \\
\hline 1 & M. Ridwan Kamil dan UU Ruzhanul Ulum & 53.749 & 32,26 & 2 \\
\hline 2 & Tubagus Hasanudin dan Anton Charliyan & 20.579 & 12,35 & 4 \\
\hline 3 & Sudrajat dan Ahmad Syaiku & 59.410 & 35,64 & 1 \\
\hline 4 & Dedi Mizwar dan Dedi Mulyadi & 32,889 & 19,74 & 3 \\
\hline & Total & 166.627 & 100 & - \\
\hline
\end{tabular}

Source: Model DB-KWK KPU Kota Sukabumi 2018 (KPU, 2018) 
The above table shows that RINDU candidates surprisingly obtained the second position of votes in Sukabumi city. The increase of votes for candidates ASYIK is correlated with the victory in Sukabumi. The result in this city is different from the trend of vote acquisition in other regencies or cities. Viewed from statistics, the vote acquisition in Sukabumi reveals that the candidates in the first and second ranks get fairly balanced. It, therefore, there is dominant votes gained in this contestation in this city.

It is tempting to study these phenomena. Especially regarding the pattern of voting behavior and its changes. Theoretically, an individual will take into account various factors that have effects in deciding to vote for a candidate or party in the general election. This process of determining a choice is called voting behavior. An analysis of voting behavior aims to see the tendency of certain social groups and their consistency to choose a particular party or candidate from one to the next election. It also aims to see the factors that make other groups change their choice and the other groups basis their choice on the loss or profit calculation.

A preliminary observation reveals that the voting results data indicate the orientation towards the candidate has the most influence on the electability. Orientation toward candidates can be explained by using a marketing approach or cognitive domain that has been developed by Newman \& Sheth (1985). Recently, studies on voting behavior have been extensively carried out and obtain diverse results as well, which contribute to enrich our understanding of the shift voting behavior of Indonesian citizens.

Employing the above theory, the author compares several previous research outputs that use the same theoretical framework. It is including a study conducted by Hapsari (2010) titled Voter Behavior in the 2009 Indonesian
Presidential Election. According to Hapsari, social image and candidate image significantly influence voter behavior in the 2009 presidential election in the Jabodetabek area. Whereas three other factors such as political issues, situational contingencies, epistemic values have less significant effects. Hapsari concludes that in the 2009 Presidential Election, the personal aspect of candidates became the main parameter of electability compared to other important variables.

The above study contrasts with the research by Widagdo (2016) titled The Role of Personnel, Emotional Bonds, and Work Programs in Influencing Voting Behavior: Approach to Political Marketing in the Election of Candidates for Village Heads. Widagdo concludes that the personal figure and emotional ties between the candidate and voter have less significant influences. Whereas, work program serves the most dominant influence in the decision-making to vote for a certain candidate. This research also proves that the voters decide rationally their choice by considering the candidate's work program instead of considering personal figures or emotional attachment to them.

Despite applying the same theoretical framework, the above two research focuses on the different context of the election and therefore draw different conclusions. The political behavior of the people in the election seems to changes flexibly depending on the preferences underlying them (Huntington \& Nelson 1994). As shown in the background of this study, certain candidates rely on their popularity have been defeated by other candidates who were noticeably less popular to the public. To explain this phenomenon or voting pattern, this study will examine two factors considered dominant in the candidate's orientation. Firstly, social image $\left(\mathrm{X}_{1}\right)$, and secondly, candidate image $\left(\mathrm{X}_{2}\right)$. This study hypothesizes that social 
image $\left(\mathrm{X}_{1}\right)$ and candidate image $\left(\mathrm{X}_{2}\right)$ partially and cumulatively influence voting behavior significantly in the 2018 West Java Gubernatorial Election.

Political phenomena can be explained from different perspectives. However, if it is related to political power, political actors, and voting behavior, behaviorism becomes the right approach to them (Wogu, 2013). To understand voting behavior, it is necessary to have come to know the extent of understanding and orientation that an individual has in his political life. This orientation and understanding are what Almond \& Verba (1990) call political culture. The orientation will guide attitudes and perceptions that will determine his or her political behavior. In this respect, it is necessary to understand the political culture to get to know one's voting behavior, political behavior, and the factors influencing voting behavior.

Based on this basis, Almond \& Verba (1990) classify political orientation into three forms: cognitive, affective, evaluative. Cognitive orientation focuses on knowledge and belief in the political system. Affective orientation concentrates on feelings towards the political system. Evaluative orientation is concerned with decisions and opinions about political objects. Political behavior can be divided into two focuses. Firstly, the political behavior of governmental institutions and officials who play a role in making, implementing, and enforcing political decisions. Secondly, citizens' behavior, either individuals or groups, whose role is to influence the authorities in carrying out their roles and functions (Surbakti, 2010).

The role of citizens is called political participation. According to Herbert McClosky (in Budiarjo 2017), political participation is a voluntary activity of citizens and the way they take part in the political process such as General Election, either directly or indirectly. Political participation aims at influencing government decisions. It comes either from individuals or collectives and could be done spontaneously, organized, continuously, or sporadically, peacefully or violently, following the rule of law or illegal, effective or ineffective (Huntington \& Nelson, 1994). The mechanism passed through this general election process is then called voting behavior. Voting behavior is related to the way someone decides to vote in a general election (Holmes, 2008). Also, Surbakti (2010) states that voting behavior is an activity of making decisions to vote or not to vote in any general election.

General factors that influence voting behavior can be looked at from three approaches. Firstly, the sociological approach or known too as the Columbia School (The Columbia Studies). Secondly, the psychological approach or called the Michigan School (The Michigan Model). Thirdly, the rational approach (Rational Choice) (Bartels, 2010). The Columbia Studies pioneered by Paul Lazarsfeld et al. (1940) apply survey research on election to study voter behavior. This approach reveals that social groupings based on several characteristics such as economic occupation, education, social identities (age, gender, region, religion) have a significant influence on a person's voting behavior (Asfar, 2006). Besides, place of origin, social class, and family ties contribute to the stability and resistance to change (Bartels, 2010).

In response to the Columbia Studies, the Michigan School promotes a new approach known as The Michigan Model. August Campbell et al pioneered this approach and develop a concept of social psychology in the context of The Presidential Elections in 1948 and 1952 in The American Voters (Cambell, et al., 1960). This study contextualizes voting behavior in a social context and places in which an individual is seen as the center of attention. Voters are no longer attached to their social groups. Rather, a sense of 
the closeness of the individual towards the party or candidate forms a psychological urge to vote. Socialization in several social environments such as family, friendship, and work environment particularly, have eventually formed partisan attitudes towards any political party. This approach emphasizes the way people's attitudes form emotional ties to political parties, political issues, and the candidate's orientation (Asfar, 2006).

As we have seen above, the previous approach did not explain the change of voting behavior from one to the next election. It also did not account for the different voting behavior from the same social or individual status. Therefore, another approach has been formed, which is known as Rational Choice. Anthony Downs introduces this approach in An Economic Theory of Democracy (1957). According to Downs (Roth 2008), rational voters will consider personal interests above the interests of others. This consideration is called self-interest axiom.

In this view, individual voters decide a choice (either party or candidate) based on personal self-interest regardless of habits or other manifestations of social ties (Heywood (2014). Moreover, this approach explicates that voters will optimize their interest in deciding on their choice. It means that they will take into consideration any advantage as a personal benefit in voting any candidate. In this approach, individuals accentuate the calculation of profit and loss in voting.

Based on the above models, Newman \& Sheth (1985) attempt to formulate certain aspects based on the actual behavior of voters in making their choice in an election. This model is known as the cognitive domain or commonly called the marketing approach. This approach integrates several established approaches by making main variables based on the voter's actual behavior. In this article, the author applies two of seven primary variables considered the most dominant influencing voting behavior. The two variables are the social image and candidate image.

Social image is an image that represents efforts to build a close relationship or the presence of candidates in certain social groups or groups classified in the minds of voters. (Newman \& Sheth, 1985). Candidates receive positive or negative stereotypes based on their relationship with various demographics factors (age, sex, religion), socioeconomic factors (income, employment), and culture and ethnicity (Newman \& Sheth, 1985). Candidates 'image refers to the prominent personality traits considered as candidates' characteristics. For example, in the 1980 American Presidential Election, Reagan had an image of a "strong leader". Whereas in the 1984 Election John Glenn used his image as a "hero" to gain support from the Democratic Party. Some other characteristics of the candidate are honest, energetic, stable, tough, articulate, stable, compassionate, and so forth (Nursal, 2004).

According to Bone \& Ranney (1971), voters will consider their choices based on instrumental and symbolic qualities. Symbolic quality is the quality of personality that should be owned by a leader. These symbolic qualities consist of four things. Firstly, life principles, such as integrity, openness, piety, independence. Secondly, emotional quality that is reflected, such as brave, strong spirited, optimistic. Thirdly, inspirational aura such as experience, persuasion power, and others. Fourthly, the social aura that represents or associated with certain groups (Nursal, 2004). Instrumental quality is the voter's trust in the candidate's personal ability to bring wealth for the people. This quality includes managerial competence such as the ability to resolve problems or make changes as well as abilities or expertise in certain fields (Nursal, 2004). 


\section{RESEARCH METHOD}

This research applies quantitative research methods. It uses surveys as a means of collecting data with explanatory research types. Explanatory research aims to explain the relationship between variables or phenomena. It intends also to confirm a phenomenon or problem (Silalahi, 2012). Respondents of this survey 140 individuals taken from the voter list, namely: the Definite Voters List (Daftar Pemilih Tetap/DPT) and the Additional List of Definite Voters (Daftar Pemilih Tambahan/DPTb) in Sukabumi City in the West Java Gubernatorial Election in 2018. Samples have been chosen through a technique of stratified random sampling. Then, the author chose respondents through the technique of simple random sampling.

The author collected data from two main sources. First, the primary data collected by questionnaires as the instrument. Second, the secondary data obtained through published sources, such as books, journals, research reports, documents, and other written materials related to this topic. The author applies the theory of the cognitive domain model developed by Newman \& Sheth (1985). The variable test uses the multinomial logistic regression analysis. With the equation

$g_{j}(x)=\beta_{j 0}+\beta_{j 1} x_{1}+\beta_{j 2} x_{2}+\ldots+\beta_{j p} x_{p}$ and 0,05 significance level and a 95 percent confidence level.

\section{RESULT AND DISCUSSION}

The author uses the Likert Scale to assess two variables, social image and candidate image, which are drawn to several questions. Then, data will be interpreted based on high and low categorization. The results of descriptive analysis of variable $\mathrm{X}$ is shown in the following table:

Table 3 Evaluation of respondents on Varable X based on candidates

\begin{tabular}{|l|l|l|l|}
\hline Candidates & Sosial image & Candidate image & Variable X \\
\hline RINDU & $3,45(69,1 \%)$ & $3,94(78,8 \%)$ & $3,70(73,95 \%)$ \\
\hline HASANAH & $2,73(54,5 \%)$ & $3,60(72,0 \%)$ & $3,17(63,25 \%)$ \\
\hline ASYIK & $3,55(70,9 \%)$ & $4,09(81,8 \%)$ & $3,82(76,35 \%)$ \\
\hline DUO DM & $3,24(64,8 \%)$ & $3,85(77,0 \%)$ & $3,55(70,90 \%)$ \\
\hline Keseluruhan & $3,24(64,83 \%)$ & $3,87(77,40 \%)$ & $3,69(71,11 \%)$ \\
\hline
\end{tabular}

Note: scores written in bold letters are high category (scales 4 to 5 )

In this West Java Gubernatorial Election in 2018 held in Sukabumi City, respondents' ratings of variable $\mathrm{X}$ based on candidates are more dominant for ASYIK candidates gaining 76.35\% (high). The second place is RINDU candidates that obtain $73.95 \%$ (high). The third rank is Duo DM candidate of $70.90 \%$ (high). The last place is Hasanah candidate gaining $63.25 \%$ (moderate). Generally, it can be explained that respondents' evaluation as a consideration in selecting candidates in the 2018 Gubernatorial Election in Sukabumi City received a high category in the aspect of social image and candidate image and overall $\mathrm{X}$ variable. However, to see the effect of these variables regression, an analysis needs to be managed.

The analysis of Logistic Regression aims to see the effect of social image variables and candidate image variables on voting behavior. The author chose this technique because the dependent variable is in the form of nominal (category) with the dependent variable category based on four pairs of candidates. Before conducting the influence test, a Goodness of Fit test must be conducted to assess how well the model is used against the data. 
Table 4 Result of Goodness of Fit Data

\begin{tabular}{llll}
\hline & Chi-Square & df & Sig. \\
\hline Pearson & 51.856 & 57 & .668 \\
\hline Deviance & 56.777 & 57 & .483 \\
\hline
\end{tabular}

Based on the above table, the test model uses the Pearson chi-square size and chi-square deviance. The result shows that both of them indicate more than 0.05 .
This means that there is a good match between the model and the data.

Hypothesis test applies the Fitting Information Model simultaneously. If the test results in the final row show sig $<0.05$ (significant test results), it can be concluded that the independent variables have a significant effect on the dependent variable.

Table 5 Result of Model Fitting Information

\begin{tabular}{lllllll}
\hline \multirow{2}{*}{ Model } & Chi-Square & $\mathrm{df}$ & Sig. & \multicolumn{2}{l}{ Likelihood Ratio Test } \\
\cline { 2 - 7 } & $\mathrm{AIC}$ & $\mathrm{BIC}$ & -2 Log Likelihood & Chi-Square & df & Sig. \\
\hline Intercept Only & 216.416 & 225.241 & 210.416 & & & \\
\hline Final & 143.573 & 205.528 & 101.753 & 108.662 & 18 & .000 \\
\hline
\end{tabular}

The above table shows that the sig value obtained in the final row is 0,000 or less than 0.01. This illustrates that the independent variables simultaneously have a significant effect on the dependent variable.

Partially, hypothesis testing uses the analysis of Likelihood Ratio Tests. For ategorical independent variables (nominal), if the probability value for an independent variable is less than 0.05 , it indicates that the independent variable is stated to have a statistically significant effect on the dependent variable.

Table 6 Result of the Likelihood Ratio Test

\begin{tabular}{lllllll}
\hline \multirow{2}{*}{ Effect } & \multicolumn{3}{l}{ Model Fitting Criteria } & \multicolumn{2}{l}{ Likelihood Ratio Test } \\
\cline { 2 - 8 } & $\begin{array}{l}\text { AIC } \\
\text { Reduced } \\
\text { Model }\end{array}$ & $\begin{array}{l}\text { of } \\
\text { MIC } \\
\text { Reduced } \\
\text { Model }\end{array}$ & $\begin{array}{l}\text {-2 Log } \\
\text { Likelihood } \\
\text { Reduced Model }\end{array}$ & Chi-Square & Df & Sig. \\
\hline X1 & 143.573 & 205.528 & $101.753 \mathrm{~b}$ & .000 & 0 &. \\
\hline X2 & 148.842 & 201.791 & $112.842 \mathrm{~b}$ & 11.088 & 3 & .011 \\
\hline
\end{tabular}

Table 6 illustrates that variables that produce probability/sig values less than 0.05 are social image (X1). Thus, with a confidence level of $95 \%$ or $\alpha=5 \%$, it can be concluded that the independent variable giving a significant partial influence on the voting behavior of respondents to candidates is the social image.

The equation of Multinomial logistic regression produces a model of $\mathrm{k}-1$. It means that the number of categories of dependent variables is reduced 1 . Since there are four categories of dependent variables, three models are generated. They are comparisons of each category with the category used as a reference (comparison). In this case, the comparison is HASANAH candidates, as their number of voters is the lowest among the other candidates.

Table 7 Matrix for Mode

11 (ASYIK vs HASANAH)

\begin{tabular}{|l|l|l|l|l|}
\hline \multirow{2}{*}{ Variables } & Sig & Pair of candidates & Chance \\
\cline { 2 - 4 } & $\mathrm{a}=5 \%$ & Asyik & Hasanah & Exp(B) \\
\hline X1 (Citra Sosial) & 0.035 & Tinggi & Rendah & 0.118 \\
\hline X2 (Citra Kandidat) & - & - & - & - \\
\hline
\end{tabular}


Table 7 shows that that only social image variables produce sig $<0.05$. The above results illustrate that if a respondent evaluates the low Social Image Aspect then he or she will choose ASYIK candidates with a proportion of 0.118 times compared to HASANAH candidates. It could be also said that a respondent will choose ASYIK candidates if he or she has a high assessment of the Social Image Aspect compared to choosing HASANAH candidates.

Tabel 8 Matrix for Model 2 (RINDU vs HASANAH)

\begin{tabular}{|l|l|l|l|l|}
\hline \multirow{2}{*}{ Variables } & Sig & Pair of candidates & chance \\
\cline { 2 - 4 } & $\mathrm{a}=5 \%$ & Rindu & Hasanah & $\operatorname{Exp}(\mathrm{B})$ \\
\hline X1 (Citra Sosial) & 0.08 & Tinggi & Rendah & 0.08 \\
\hline X2 (Citra Kandidat) & - & - & - & - \\
\hline
\end{tabular}

Table 8 shows that only social image variables produce sig $<0.05$. The above results illustrate that if a respondent evaluates the low Social Image Aspect then he or she will choose the RINDU Candidate with a proportion of 0.080 times compared to the HASANAH Candidate. It could also be said that a respondent will choose RINDU Candidate if he has a high assessment of the Social Image Aspect compared to choosing HASANAH Candidate.

In model 3 test (Duo DM vs HASANAH), the social image variable and the candidate image did not generate sig $<0.05$ in the sense that both pairs had the same low rating from respondents. In other words, the two pairs of candidates did not have a significant effect viewed from these variables.

The result of this research indicated that, partially, aspects of the social image have a significant effect on voting behavior. This means that the symbolic qualities that the candidates have such as association to certain social groups young people, religious leaders, or the alignments with the "wong cilik" small ordinary people) give great interest to voters. From the assessment results (see table 3), two candidates obtained high categories. RINDU Candidates got $69.1 \%$ and ASYIK Candidate gained $70.9 \%$. Likewise in the multinomial regression test, the two pairs of candidates received a sig $<0.05$ high rating on the aspect of social image.
Breaking down to several indicators, two factors of consideration in choosing (representation of young figures and representation of Islamic figures) have a variety of data and get high categories. In terms of the young figure indicator, RINDU Candidates obtained the most dominant value, $73.8 \%$. It could be said that RINDU Candidates successfully portray themselves as young figure 'favored by millennials'. Looking at public responses, we can see cases published by Haq (2018), in which "hearing the jargon Rindu, Hilda feels it is the jargon of young people and young leaders". Another response is from Eko, who states that "the word" Rindu ", an abbreviation of Ridwan and Uu, looks not dashing and feels ,alay' (too dramatized). He argues that it is probably coming from Ridwan Kamil who is is a social media activist. The word Rindu is suitable for his existence and fit with Emil's melancholy character. These cases prove that the image of candidates as figures close to millennials can touch the youngsters' cohort.

Other indicators of making choice due to being considered to represent Islamic figures became the indicator with the highest assessment in the aspect of social image. This indicator was more dominant in ASYIK Candidates who obtained the highest score of $90.3 \%$. This pair of candidates managed to target the religious voters' group. People in West Java Province are known as religious and conservative. Some areas are called the 
city of students of the religious school (santri), including the City of Sukabumi identified with heavy Islamic symbols. In this respect, ASYIK Candidates claim as "the candidate chosen by the religious leader" or "chosen leaders who love Islam and glorify the ulama". This is likely because this Candidate is the only true Islamic figure and supported by the ulama group. The claim has convinced the voter and win their hearts for support from the groups of religious voters and swing voters.

Other studies indicate that candidate's image does not significantly influence voting behavior in this city. The symbolic quality of candidates reflected through life principles such as integrity, honesty, religiosity, and emotional aura such as being assertive, intelligent, broadminded, does not seem to influence voting behavior much. Although descriptive assessment shows that the candidate image variable obtained a high category (79.3\%), it did not significantly impact on the logistic regression test. This result indicates that voters assume all candidates in the 2018 West Java Gubernatorial Election have symbolic qualities that should be owned by leaders. It, therefore, there is no distinguishing factor between one candidate and another candidate. Thus, it does not have a significant effect.

\section{CONCLUSION}

Simultaneously, aspects of social image and candidate image influence voting behavior in the 2018 Gubernatorial Election in Sukabumi City. However, partially, the social image has a significant influence. Whereas the image of a candidate has no significant effect. Using the cognitive domain, this study shows that voting behavior in Sukabumi City can be categorized in the psychological approach to 'feelings and emotional closeness'.

Not all voters have the capacity to think, analyze, and evaluate what they need. Therefore, the voters prioritize 'shortcuts' such as identification of certain figures with a sense of closeness. The evaluation of candidates' ability to fight for the public aspirations, candidates' characters, has turned to become only the second parameter compared to feelings towards certain figures. It, therefore, the aspect of a candidate's image does not have a significant effect on voting behavior.

The phenomenon of the increase of votes on ASYIK Candidates that disproves the pre-election survey has shown in this research. Especially the way ASYIK Candidates managed to outstrip Duo DM Candidates and almost champion at the West Java Level. Another factor that makes ASYIK Candidates won in Sukabumi City is due to this candidate obtained dominant results, especially in the aspect of social image. The symbolic quality shown through the social aura is a more dominant influence on the voters' behavior, particularly in the religious voter group.

\section{BIBLIOGRAPHY}

Almond, G. A. \& Verba, S. (1990). Budaya Politik : Tingkah Laku Politik dan Demokrasi di Lima Negara. Terjemahan S. Simamora. Jakarta: Bumi Aksara.

Asfar, M. (2006). Pemilu dan Perilaku Memilih 19552004. Surabaya: Pustaka Eureka.

Bartels, L. M. (2010). The Study of Electoral Behavior. J. E. Leighley (Ed). The Oxford Handbook of American Elections and Political, 1987: 1-48.

Budiarjo, M. (2017). Dasar-Dasar Ilmu Politik Edisi Revisi. Edisi 14nd. Jakarta: PT Gramedia Pustaka Utama. Bone, H. A. \& Ranney, A. (1971). Politics And Voters. Edisi 3nd. New York: McGraw-Hill Book Company.

Campbell, A. et.al. (1960). The American Voter. New York: John Wiley \& Sons.

Downs, A. (1957). An Economic Theory of Democracy. New York: Harper \& Row.

Hapsari, C.H.C. (2010). Perilaku Pemilih Dalam Pemilihan Umum Presiden Indonesia 2009, Tesis. Pasca Sarjana Universitas Gajah Mada.

Haq, F.U. (2018, Juni 2018). Ini Komentar Warga Soal Jargon Kandidat Pilgub Jabar. Rely on https://m.ayobandung.com/read/2018/06/ 26/34652/ini-komentar-warga-soal-jargon- 
kandidat-pilgub-jabar, tanggal 25 November 2019.

Heywood, A. (2014). POLITIK edisi ke-4. S. Sobary Mohammad (Ed). Terjemahan A. L. Lazuardi. Yogyakarta: Pustaka Pelajar.

Holmes, P. (2008). Introducing Politics for AS Level: Institutions and Issues in Perspective. Malden US: Polity Press.

Huntington, S. P. \& Nelson, J. M. (1994). Partisipasi Politik di Negara Berkembang. Terjemahan S. Simamora. Jakarta: Rineka Cipta.

Lazarsfeld, P.F. et.al (1944). The People's Choice: How the Voter Makes Up His Mind in a Presidential Campaign. New York: Columbia University Press

Newman, B. I. \& Sheth, J. N. (1985). A Model of Primary Voter Behavior. The Journal of Consumer Research. 12:179-187.

Nursal, A. (2004). Political Marketing : Strategi Memenangkan Pemilu. Jakarta: PT. Gramedia Pustaka Utama.

Roth, D. (2008). Studi Pemilu Empiris: Sumber, Teori-Teori, Instrumen dan Metode. D.
Ambardi (Ed). Terjemahan D. Matindas. Jakarta: Friderich-Naumann-Stiftung fur die Freihit.

Silalahi, U. (2010). Metode Penelitian Sosial. Bandung: Refika Aditama.

Surbakti, R. (2010). Memahami Ilmu Politik. Jakarta: Kompas Gramedia.

Widagdo, S. (2016). Peran Ketokohan, Ikatan Emosional Dan Program Kerja Dalam Memengaruhi Perilaku Memilih (Pendekatan Pemasaran Politik Dalam Pemilihan Calon Kepala Desa). Prosiding Seminar Nasional, Gedung Pascasarjana FEB UNEJ. Dinamika Global: Rebranding Keunggulan Kompetitif Berbasis Kearifan Lokal. Jember 17 Desember 2016.

Wogu, I. A. (2013). An Analysis Of The Philosophical Foundation of Behaviouralism \& constructivism: Any Imperative to Modern Political Science?. International Journal of Research in Social Sciences. 2(3): 63-71 